\title{
Is er nog een verzekeringsgeneeskundig referentiekader?
}

\author{
Jan Besseling
}

Bij de voorbereiding van een expertmeeting over factoren die van invloed zijn op het risico voor jongeren om hun arbeidscarrière te starten als Wajongere, zijn we gestart met het beschrijven van enkele relevante theorieën die we waren tegengekomen. Niets is zo praktisch als een goede theorie. Bestuurskundige theorieën staan zeer kritisch tegenover doelgroepenbeleid en pleiten voor generiek beleid. Bevoorrechting van specifieke groepen zuigt niet alleen de doelgroep de regeling in, maar heeft bovendien een onbedoelde stigmatiserende werking. De WAO kende een aanzuigende werking met verborgen werkloosheid. Het lijkt erop dat ook de introductie van de Wajong als specifieke regeling in I996 een aanzuigende werking heeft gehad.

We hebben tijdens die expertmeeting geen verklaring of theorie opgevoerd vanuit de verzekeringsgeneeskunde. De vraag is echter of er wel een breed gedragen theorie is die we hadden kunnen opvoeren. Het laatste halfjaar zijn verschillende langdurige onderzoekstrajecten afgesloten met een promotie door een verzekeringsgeneeskundige. Wat daarbij opvalt, is dat de proefschriften geen gemeenschappelijk theoretisch referentiekader hebben. In de tijd dat ik nog werkte bij de afdeling Onderzoek van de GMD werd de meeste kennis ontwikkeld vanuit het zogeheten verzekeringsgeneeskundig referentiekader. Degenen die het hier niet mee eens waren, gaven aan op welke punten hun uitgangspunten ervan afweken. De recente promoties starten echter vanuit verschillende concepten en opvattingen over het model dat de claimbeoordeling van de verzekeringsgeneeskundige beschrijft. Dat roept bij mij als buitenstaander de vraag op of er nog wel een gemeenschappelijk referentiekader voor de verzekeringsgeneeskunde is en wat dat dan is.
De onlangs verschenen bundel Innovatieve voorstellen voor sociaal-medische beoordeling van arbeidsvermogen illustreert dat er geen gemeenschappelijk referentiekader (meer) is. De auteurs was verzocht om, in navolging van het advies van de Gezondheidsraad, het ICF-model als generiek conceptueel model te beproeven. De redactie van de bundel komt (ook) tot de conclusie dat de auteurs de kennisontwikkeling en innovatieve ideeën niet binnen een gezamenlijk conceptueel kader hebben beschreven. Deels komt dat doordat er een tweedeling is ontstaan. Enerzijds is er nog steeds, net als bij de WAO, de claimbeoordeling om verlies aan verdiencapaciteit te compenseren. Anderzijds is echter in toenemende mate sprake van participatiegerichte beoordelingen zoals in de nieuwe Wajong. Met de term arbeidsvermogen wordt niet meer geduid op verdiencapaciteit, maar welke vormen van arbeid een persoon succesvol zou kunnen uitoefenen, onder welke technische en organisatorische randvoorwaarden. De auteurs in de bundel hanteren zeer uiteenlopende theoretische vertrekpunten. De redactiecommissie lijkt dat te betreuren, al kiest ze voor een brede conclusie: 'De toekomst zal uitwijzen of een integratief theoretisch kader voor SMBA mogelijk en wenselijk is en wat de betekenis van het ICF-model daarvoor is.'

Wat dat betreft, ligt er een uitdaging voor de twee hoogleraren op de bijzondere leerstoelen verzekeringsgeneeskunde die dit jaar benoemd worden bij VU en UvA. Mijns inziens staan ze voor de uitdaging om te komen tot één theoretisch kader met breed gedragen concepten en om kennisontwikkeling vanuit eenzelfde theoretisch en conceptueel kader te stimuleren. We weten immers waar het toe leidt, als we in de sociale zekerheid duizend bloemen laten bloeien. 